УДК 330.3

\title{
АКТУАЛІЗАЦІЯ КОНЦЕПЦІЇ КОРПОРАТИВНОЇ СОЦІАЛЬНОÏ ВІДПОВІДАЛЬНОСТІ В МОДЕЛІ ЕКОНОМІЧНОГО РОЗВИТКУ УКРАЇНИ
}

\section{ACTUALIZATION OF THE CONCEPT OF CORPORATE SOCIAL RESPONSIBILITY IN THE MODEL OF ECONOMIC DEVELOPMENT OF UKRAINE}

\author{
Ситник Йосиф Степанович \\ доктор економічних наук, доцент, \\ Національний університет «Львівська політехніка» \\ ORCID: https://orcid.org/0000-0001-8718-5738 \\ Юрченко Галина Миколаївна \\ аспірантка, \\ Національний університет «Львівська політехніка» \\ ORCID: https://orcid.org/0000-0002-6265-2835 \\ Sytnyk Yosyf, Yurchenko Halyna \\ Lviv Polytechnic National University
}

\begin{abstract}
Статтю присвячено актуальним питанням узагальнення основних теоретичних положень та визначенню особливості процесу формування концепції корпоративної соціальної відповідальності в контексті забезпечення сталого розвитку та сприяння соціально-економічному прогресу України. Розглянуто теоретико-методологічні та прикладі аспекти концепції корпоративної соціальної відповідальності. Зокрема, на основі емпіричного аналізу літературних та статистичних джерел та їх узагальнення визначено ознаки та подано авторське трактування сутності концепції корпоративної соціальної відповідальності, розроблено грасрічну інтерпретацію сутності моделі, продемонстровано її циклічність. Результатом проведеного дослідження стало розширення змістовного наповнення концепції корпоративної соціальної відповідальності за допомогою уточнення підходів до розуміння концепції з позиції різних ключових гравців, переваг зацікавлених сторін, механізмів запровадження корпоративної соціальної відповідальності урядом та підприємствами. Розроблено цілісну модель підходів до трактування й впровадження КСВ різними гравцями.
\end{abstract}

Ключові слова: сталий розвиток, корпоративна соціальна відповідальність, соціальна економіка, соціальний розвиток, економічний розвиток.

Статья посвящена актуальным вопросам обобщения основных теоретических положений и определению особенности процесса формирования концепции корпоративной социальной ответственности в контексте обеспечения устойчивого развития и содействия социально-экономическому прогрессу Украины. Рассмотрены теоретико-методологические и практические аспекты концепции корпоративной социальной ответственности. В частности, на основе эмпирического анализа литературных и статистических источников и их обобщения определены признаки и представлена авторская трактовка сущности концепции корпоративной социальной ответственности, разработано графическую интерпретацию сущности модели, продемонстрировано ее цикличность. Результатом проведенного исследования стало расширение содержательного наполнения концепции корпоративной социальной ответственности с помощью уточнения подходов к пониманию концепции с позиции различных ключевых игроков, преимуществ заинтересованных сторон, механизмов внедрения корпоративной социальной ответственности правительством и предприятиями. Разработана целостная модель подходов к трактовке и внедрение корпоративной социальной ответствености различными игроками.

Ключевые слова: устойчивое развитие, корпоративная социальная ответственность, социальная экономика, социальное развитие, экономическое развитие.

The article is devoted to topical issues of generalization of the main theoretical provisions and defining the peculiarities of the process of forming the concept of corporate social responsibility in the context of ensuring sustainable development and promoting socio-economic progress of Ukraine. Theoretical, methodological and practical aspects 
of the concept of corporate social responsibility are considered. In particular, based on empirical analysis of foreign and domestic literary and statistical sources, the features and author's interpretation of the essence of the concept of corporate social responsibility were identified, key players in corporate social responsibility were identified and a graphical interpretation of the essence of the tripartite model of corporate social responsibility was developed. The cyclical nature of interaction between the state, entrepreneurs and society was analyzed and demonstrated. The result of the study was to expand the content of the concept of corporate social responsibility by refining approaches to understanding the concept from the standpoint of various key players. The necessity and advantages of socially responsible behavior as a condition are substantiated formation of competitiveness of enterprises in modern society. The necessity of promoting the culture of social responsibility as a condition for the formation of a self-regulating economy is substantiated. An analysis of existing approaches to the introduction of corporate social responsibility by the government, enterprises and society was conducted. A holistic graphical model of approaches to the interpretation and implementation of corporate social responsibility by different players has been developed. The advantages for the micro- and micro-environment of the enterprise, which arise as a result of effective integration of the model of corporate social responsibility into the policy of the enterprise, were highlighted, the influence of each of the elements was demonstrated. An analysis of the prospects for the development of the model of corporate social responsibility in the current economic and social conditions of Ukraine, predicts the optimal approach to the implementation of corporate social responsibility and provides a number of recommendations for the government.

Keywords: sustainable development, corporate social responsibility, social economy, social development, economic development.

Постановка проблеми. Екологічні, економічні та соціальні виклики глобалізації вимагають пошук такої економічної моделі, що гарантуватиме збалансований та постійний розвиток. Власне, така фрілософрія лежить в основі концепції сталого розвитку [1] - це постійний соціально-економічний та науковотехнічний розвиток, який не знищує, а сприяє відновленню природної основи та добробуту населення. Окрім цього на сьогодні людський фрактор виробництва $€$ основою соціальноекономічного розвитку [2]. Традиційно соціальна сорера розвитку $є$ похідною від економічної: лише на етапі високорозвиненого індустріального виробництва створюються матеріальні умови для підвищення добробуту населення. Але сьогодні конкурентоспроможність визначається здебільшого якістю робочої сили. Тому все частіше розвиток людини через задоволення ії̈ духовних та розумних матеріальних потреб вважається критерієм соціально-економічного прогресу. 3 огляду на це, неминучою є зміна парадигми щодо мети підприємництва як максимізації прибутку та перерозподілу благ, адже, тепер підприємництво $€$ радше джерелом росту суспільного благополуччя, а перерозподіл благ усвідомлюється більше як шлях до цього. Така парадигма вимагала поступового фрормування нової концепції фрункціонування економічного сектору, яка отримала назву концепція соціальної відповідальності.

Аналіз останніх досліджень і публікацій. Аналіз наукових джерел свідчить, що потребу інноваційних моделей регулювання державної економіки та особливості процесів покращення соціального потенціалу під- приємств досліджувалися у наукових працях Колота А., Бабаєва Л., Будєєва І., Грішнова О., Берестова Л., Боброва Є., Акімова І. та інші. Вагомий вклад у становлення, розвиток і дослідження особливостей соціально-відповідального підходу до ведення підприємницької діяльності внесли зарубіжні та вітчизняні вчені, а саме: Х. Боуена, Г. Ганта, Г. Беккер, М. Блауг, М. Фрідмена, Е. Карнегі, О. Тіда, Т. Бредгард, П. Друкер, А. Керолл, Ф. Котлер, М. Мескон, Дж. Мун, Л. Ненсі, О. Грішнова, А. Колот, В. Нижник, О. Осінкіна, І. Петрова, Ю. Саєнко, О. Степанова, О. Філіпченко, П. Яницький, Н. Брюховецький, С. Черних, Т. Калінеску та іншим. На думку Т. Калінеску [3], правильний вибір стратегії управління соціальним розвитком $\epsilon$ запорукою ефективного фрункціонування підприємства в умовах соціальної економіки, і повинен передбачати загальний напрям дій з розвитку ефрективності роботи працівників у сумі із задоволенням потреб акціонерів, споживачів, партнерів, постачальників, суспільства.

Питання корпоративної соціальної відповідальності і сталого розвитку досліджували такі українських і зарубіжних учені, як А. Амош, В. Гейц, С. Перегудов, В. Гриньов, А. Гриненко [4], О. Новіков, М. Боровик, М. Дороніна. Втім, спостерігається розбіжність у думках, наприклад, А. Гриненко вважає корпоративну соціальну відповідальність інструментом соціальної політики підприємства, яка полягає у соціальному страхуванні, соціальних виплатах, створенні робочих місць, гідній заробітній платі, відповідальності перед споживачами та інше. У той же час Всесвітня ділова рада [5] за сталий розвиток трактує корпоративну 
соціальну відповідальність як обов'язок підприємств сприяти сталому розвитку через співпрацю з працівниками, громадою та суспільством для покращення їх життя.

Виділення невирішених раніше частин загальної проблеми. Україна обрала соціальний орієнтир у економічному розвитку, а виклики глобалізації зумовлюють необхідність впровадження інноваційних економічних моделей для урівноваження економічного розвитку та соціального благополуччя населення, тоді як комплексне трактування категорії корпоративної соціальної відповідальності, аналізу моделі цієї концепції та її впливу на різні зацікавлені сторони досі залишаються не дослідженими.

Формулювання цілей статті (постановка завдання). Метою статті $€$ дослідження концепції корпоративної соціальної відповідальності як напрямку соціально-економічного прогресу, обгрунтувати їі роль у реалізації концепції сталого розвитку, дослідження підходів до її трактування, розуміння та моделі реалізації, оцінка передумов та рівня розвитку корпоративної соціальної відповідальності в Україні.

Виклад основного матеріалу дослідження. У доповіді Міжнародної комісії з навколишнього середовища і розвитку під назвою «Наше спільне майбутнє» (1997р.) сталий розвиток визначався керівним принципом діяльності ООН, урядів, приватних та неурядових організацій, був прийнятий більше ніж 180 країнами світу і охопив розуміння цілісного, збалансованого та стабільного розвитку економічних, соціальних, науково-технічних та екологічних параметрів. Інституційно-організаційним механізмом втілення концепції сталого розвитку $є$ система соціального партнерства держави, підприємницького сектору та соціуму. Концепція «сталого розвитку» $є$ розвитком вчення В. Вернадського [6] про ноосферу, у якій він зазначав, що: «питання про планову, однакову діяльність з метою оволодіння природою і правильного розподілу багатств пов'язане з усвідомленням єдності і рівності усіх людей, єдності нооссрери...». Необхідність запровадження принципів сталого розвитку при проектуванні розвитку національної економіки України ставить перед вченими завдання пошуку нових концепцій та механізмів їх реалізації на практиці. Втім, реалізація даної концепції здатна зруйнувати соціальну нерівність, яка виникла в наслідок технологічних інновацій, і блокувати системне збагачення окремих людей, що існує у комплексі із зростанням срінансових труднощів у інших.
Так у 50-х років двадцятого століття зародилось поняття соціальної відповідальності, однак популярності воно набуло лише в останні десятиріччя у деяких країнах Європи та у США. В Україні ж увагу до концепції соціальної відповідальності бізнесу стали приділяти лише у 21 столітті, тоді, коли залучення іноземного капіталу та вихід вітчизняних підприємств на іноземні ринки в умовах європейської інтеграції, стало неможливим без політики соціальної відповідальності підприємницького сектору.

На сьогодні не існує єдиного трактування поняття корпоративної соціальної відповідальності (далі - КСВ).

На нашу думку, існує необхідність у більш широкому охопленні фрілософрії концепції КСВ у визначенні цієї категорії, тому ми пропонуємо узагальнене трактування корпоративної соціальної відповідальності, як моделі трьохсторонніх відносин держава - суспільство підприємницький сектор для урівноваження існуючих економічних та соціальних нерівностей з метою довгострокового збільшення прибутку через добровільну діяльність підприємницького сектору, спрямовану на дотримання високих стандартів у виробництві продукції, наданні послуг та у роботі з персоналом, а також на задоволення потреб громади, вирішення ії̈ проблем та на зменшення шкідливого впливу на навколишнє середовище.

Стверджуючи, що КСВ це трьохстороння модель, безумовний учасником якої $€$ держава, варто зазначити, що на сьогодні можна виокремити дві моделі урядового підходу до КСВ: американську та європейську. В американській моделі ініціатива із запровадження КСВ належить підприємствам, які самостійно можуть визначати свій суспільний внесок. Державне регулювання у цій моделі $\epsilon$ незначним, хоч і передбачає відповідні податкові пільги при соціальному інвестуванню у вигідні для соціуму сорери, а також заходи з популяризації підприємства, що інвестують у соціальну інфрраструктуру. У той час як європейська модель КСВ - це система заходів державного регулювання. Тенденція глобалізації в економіці та активне запровадження обов'язкової публікації соціальної звітності, розробленою відповідно до міжнародних стандартів (табл. 2) сприяють поширенню концепції корпоративно-соціальної відповідальності.

Інший гравець цієї моделі - підприємницький сектор, для якого КСВ $є$ інвестицією у лояльність працівників, у купівлеспроможність та прихильність споживачів, у стійке партнер- 
Таблиця 1

Визначення категорії «корпоративна соціальна відповідальність»

\begin{tabular}{|c|c|c|}
\hline № & Джерело & Визначення \\
\hline 1 & Г. Боуєн & $\begin{array}{l}\text { «Реалізації такої політики, прийнятті таких рішень або вибору такої } \\
\text { лінії поведінки, які були би бажаними з позицій цілей і цінностей } \\
\text { суспільства» [7] }\end{array}$ \\
\hline 2 & М. Фрідмен & $\begin{array}{l}\text { «Використовувати свої ресурси та займатися діяльністю, } \\
\text { спрямованою на збільшення прибутку, за умови, що він } \\
\text { додержується правил гри, тобто бере участь у відкритій вільній } \\
\text { конкуренції без обману та шахрайства» [8] }\end{array}$ \\
\hline 3 & А. Керолл & $\begin{array}{l}\text { «Діяльність компанії, що відповідає економічним, правовим, } \\
\text { етичним і дискреційним очікуванням, що пред'являються } \\
\text { суспільством організації у даний період вимогам суспільства» [9] }\end{array}$ \\
\hline 4 & П. Друкер & $\begin{array}{l}\text { «Полягає у перетворенні соціальних проблем в економічну } \\
\text { можливість і економічний зиск, виробничі потужності, } \\
\text { компетентність персоналу, добре оплачувану роботу і, зрештою, } \\
\text { багатство» [10] }\end{array}$ \\
\hline 5 & $\begin{array}{c}\text { Міжнародна } \\
\text { організація праці }\end{array}$ & $\begin{array}{l}\text { «Добровільна ініціатива ділових кіл, яка стосується діяльності, } \\
\text { що перевищує просту вимогу дотримання букви закону» [11] }\end{array}$ \\
\hline 6 & $\begin{array}{l}\text { Всесвітня бізнесова } \\
\text { рада із сталого } \\
\text { розвитку (WBCSD) }\end{array}$ & $\begin{array}{l}\text { «Зобов'язання бізнесу сприяти сталому економічному розвиткові, } \\
\text { працюючи з найманими працівниками їхніми родинами, місцевою } \\
\text { громадою та суспільством загалом з метою покращення якості } \\
\text { життя» [12] }\end{array}$ \\
\hline 7 & $\begin{array}{l}\text { Міжнародний } \\
\text { форум лідерів } \\
\text { бізнесу (IBLF) }\end{array}$ & $\begin{array}{l}\text { «Сприяння відповідальній діловій практиці, яка дає вигоду бізнесу } \\
\text { та суспільству й допомагає досягти економічного, соціального та } \\
\text { екологічного усталеного розвитку через максимальне збільшення } \\
\text { позитивного впливу бізнесу на суспільство з одночасною } \\
\text { мінімізацією його негативного впливу» [13] }\end{array}$ \\
\hline 8 & $\begin{array}{l}\text { Меморандум } \\
\text { про соціальну } \\
\text { відповідальність } \\
\text { бізнесу в Україні }\end{array}$ & $\begin{array}{l}\text { «Відповідальне ставлення будь-якої компанії до свого продукту } \\
\text { або послуги, споживачів, працівників, партнерів, активна соціальна } \\
\text { позиція компанії, яка полягає у гармонійному співіснуванні, } \\
\text { взаємодія та постійний діалог із суспільством, участь у вирішенні } \\
\text { найгостріших соціальних проблем» [14] }\end{array}$ \\
\hline 9 & В. Воробей & $\begin{array}{l}\text { «Спосіб управління бізнес-процесами з метою забезпечення } \\
\text { позитивного впливу на суспільство» [15] }\end{array}$ \\
\hline 10 & $\begin{array}{l}\text { О. Зінченко, } \\
\text { А. Харченко }\end{array}$ & $\begin{array}{l}\text { «Конкурентна перевага успішно фрункціонуючого підприємства, } \\
\text { завдяки якій невиробничі витрати підприємства примножують } \\
\text { його ринкову вартість за рахунок колективного інтелектуального } \\
\text { капіталу та гудвілу, конкурентоспроможність продукції, послуг } \\
\text { і сприяють вирішенню соціальних, екологічних та економічних } \\
\text { проблем суспільства» [16] }\end{array}$ \\
\hline 11 & А. Колот & $\begin{array}{l}\text { «Імплементований у корпоративне управління певний вид } \\
\text { соціальних зобов'язань (здебільшого добровільних) перед } \\
\text { працівниками, партнерами, інститутами громадського суспільства } \\
\text { і суспільством у цілому» [17] }\end{array}$ \\
\hline 12 & Н. Супрун & $\begin{array}{l}\text { «Комплекс цінностей, заходів і процесів, що відображають } \\
\text { добровільне зобов'язання компанії щодо реалізації соціальних } \\
\text { ініціатив (як у внутрішньому, так і в зовнішньому середовищі), } \\
\text { результати яких сприятимуть підвищенню конкурентоспроможності } \\
\text { організації у довгостроковій перспективі, зміцненню її ділової } \\
\text { репутації, вирішенню завдань сталого розвитку організації та } \\
\text { суспільства в цілому» [18] }\end{array}$ \\
\hline
\end{tabular}




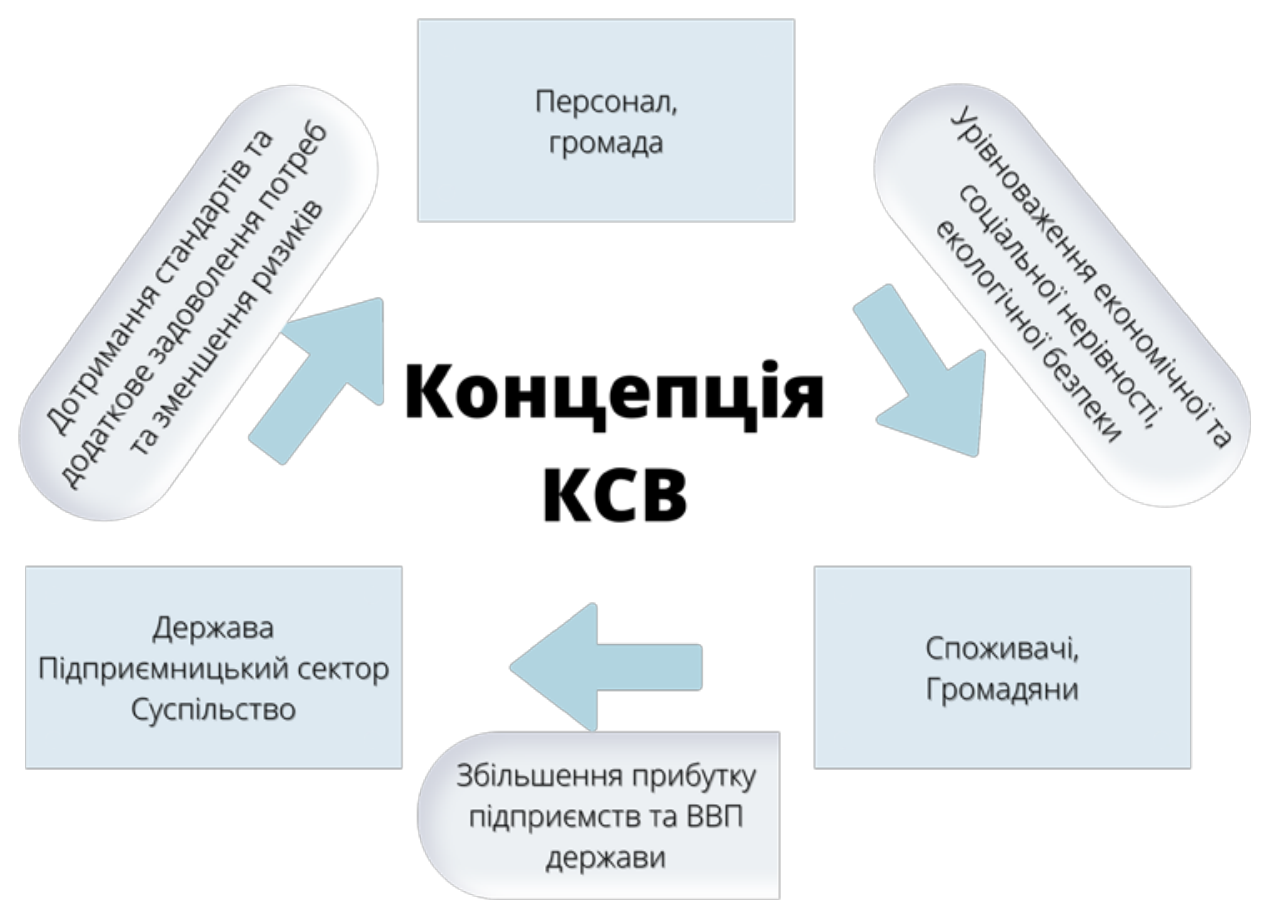

Рис. 1. Модель корпоративної соціальної відповідальності

Джерело: розробка авторів

ство, підтримку уряду та громади, комунікацію зі ЗМІ і, в сумі - у майбутнє підприємства. Відповідно до концепції КСВ Арчі Керолла [19], виокремлено три підходи розуміння КСВ, які базуються на рівні сприйняття соціальної відповідальності саме підприємствами:

- «корпоративний» стверджує, що єдиною відповідальністю підприємства $є$ використання своїх ресурсів та енергії в діях, що ведуть до збільшення прибутків, до поки це відповідає правилам гри;

- «розумний егоїзм» - соціальна відповідальність розглядається як засіб досягнення довгострокових переваг, тобто, витрачаючи кошти на соціальні програми, підприємство зменшує свої поточні прибутки, але у довгостроковій перспек- тиві створює сприятливе соціальне оточення, а разом із цим - стійкі прибутки;

- «корпоративний альтруїзм» - підприємство повинне враховувати всі аспекти свого впливу на зацікавлені групи та суспільства та вносити значний внесок у покращення якості життя суспільства.

Формами прояву соціальної відповідальності підприємства $€$ корпоративне громадянство та соціальна політика підприємства. Корпоративне громадянство являє собою зовнішню форму прояву і полягає у діяльності підприємства, свідомо орієнтованої на вирішення суспільно корисних завдань, до яких не зобов'язує законодавство і у яких немає прямого економічного інтересу. У той же час,

Ключові міжнародні стандарти корпоративно-соціальної відповідальності

\begin{tabular}{|c|l|}
\hline Назва & \multicolumn{1}{|c|}{ Сутність } \\
\hline OHSAS 18001 & $\begin{array}{l}\text { Стандарт перевірки системи менеджменту охорони праці та промислової } \\
\text { безпеки, задовольняє потребу в ефективній роботі з охорони праці та } \\
\text { здоров'я }\end{array}$ \\
\hline SA 8000 & $\begin{array}{l}\text { Стандарт покращення умов праці на підприємствах, захищає права } \\
\text { та можливості усього персоналу у сфері контролю та впливу компанії }\end{array}$ \\
\hline AA 1000 & $\begin{array}{l}\text { Стандарт етичної та соціальної діяльності підприємств, полягає в інтеграції } \\
\text { соціальних аспектів у організацію підприємництва. }\end{array}$ \\
\hline ISO 14001 & $\begin{array}{l}\text { Стандарт систем екологічного менеджменту для зменшення забруднення } \\
\text { навколишнього середовища }\end{array}$ \\
\hline ISO 26000:2010 & $\begin{array}{l}\text { Стандарт взаємодії із зацікавленими сторонами, полягає в інтеграції } \\
\text { соціально відповідальної поведінки в організацію }\end{array}$ \\
\hline
\end{tabular}


соціальна політика підприємства є внутрішнім проявом і полягає у системі цілеспрямованих послідовних дій менеджменту підприємства, що спрямовані на задоволення духовних та матеріальних потреб працівників організації.

Науковцями ще не виокремлено підходи до розуміння КСВ суспільством, яке $є$ третій гравцем моделі, втім, на нашу думку, в цьому контексті варто передбачати дві групи соціуму споживачів ринку та учасників ринку праці, для обох показником лояльності до концепції КСВ може стати коесріцієнт прихильності до підприємств 3 високим рівнем політики КСВ: перші здатні обрати іншого постачальника товарів чи послуг за усіх однакових умов лише тому, що постачальник веде соціально відповідальну корпоративну політику, а другі - вірні своєму роботодавцю, навіть за умови не значного програшу у посадовому окладі, лише тому, що роботодавець впроваджує соціально відповідальну корпоративну політику. Дослідження Mintel: Global Market Research \& Market Insight 1998 року засвідчують, що 50\% британських споживачів [20] готові купувати інший бренд, якщо його пропонує соціально-відповідальне підприємство. Цей же показник у США сягає понад 66\%. Це очевидно, адже, нематеріальні активи більшості іноземних підприємств перевищують матеріальні активи, до прикладу, за оцінками консалтингової компанії Interbrand співвідношення матеріальних та нематеріальних активів Coca-Cola становить 4 до 96 [21]. Значну частину нематеріальних активів складає вартість бренду, яка, у свою чергу, визначається репутацією, а та - форомується з-поміж іншого й на основі соціально-відповідальної поведінки підприємства. Таким чином очевидно, що не зважаючи на додаткові витрати, які несе за собою соціальна відповідальність, підприємство все одно отримує ряд переваг у макро- та мікросередовищі, що подано у таблиці 3.
Таким чином бачимо, що розуміння корпоративної соціальної відповідальності відрізняється у залежності від позиції гравця моделі. Узагальнену модель підходів до розуміння концепції корпоративної соціальної відповідальності з позиції різних ключових гравців подано на рисунку 2.

Таким чином бачимо, що соціальна активність виходить за межі благодійності підприємців і стає частиною бізнес-процесів, адже, навколо соціальних інвестицій формується образ та репутація підприємства, тобто, концепція корпоративної соціальної відповідальності розширює завдання підприємства поза рамки прагнення до максимізації прибутку, а соціальні результати підприємств формуватимуть зацікавленість працівників, встановлюватимуть надійне партнерство, забезпечить прихильність нових партнерів, сприятиме зростанню купівельної спроможності споживачів та розширенню ринку збуту. Впровадження програм корпоративної соціальної відповідальності забезпечує встановлення тісних стосунків між державою, суспільством та підприємницьким сектором, забезпечує зростання соціальної захищеності населення і в цілому сприяє соціально-економічному прогресу держави.

Підприємницький сектор України на сьогодні не усвідомлює своєї ролі та відповідальності у соціальному розвитку держави, і навіть не бачить власних стратегічних інтересів. Так опитування показало, що більшість підприємств не має стратегії соціальної відповідальності, а утотожнюють КСВ із дотриманням законодавства та епізодичними благодійними проектами. Хоча саме стратегія корпоративної соціальної відповідальності сприяє фрормуванню та нарощенню соціального капіталу підприємства, стабілізує ринок зайнятості та підвищує ефрективність мотивації працівни-

Переваги підприємства від реалізації політик соціальної відповідальності

\begin{tabular}{|c|c|}
\hline Макросередовище & Мікросередовище \\
\hline $\begin{array}{l}\text { - створення сприятливого та стабільного } \\
\text { середовища для ведення підприємницької } \\
\text { діяльності } \\
\text { - зміцнення репутації, іміджу та зростання } \\
\text { довіри від зацікавлених сторін } \\
\text { - зростання інвестиційної привабливості } \\
\text { підприємства } \\
\text { - можливості для залучення } \\
\text { висококвалісрікованого персоналу } \\
\text { - підтримка зі сторони держави та світових } \\
\text { організацій }\end{array}$ & $\begin{array}{l}\text { - зростання вартості акцій та підвищення } \\
\text { срінансової ефективності } \\
\text { - зменшення ризиків } \\
\text { - економія коштів, що інвестувались } \\
\text { у економічну безпеку } \\
\text { - зростання обсягу продажів та підвищення } \\
\text { ефективності маркетингової політики } \\
\text { - зменшення витрат на управління } \\
\text { персоналом через зростання лояльності } \\
\text { працівників, покращення мікроклімату } \\
\text { на підприємстві та зростання підтримки дій } \\
\text { менеджменту зі сторони працівників }\end{array}$ \\
\hline
\end{tabular}




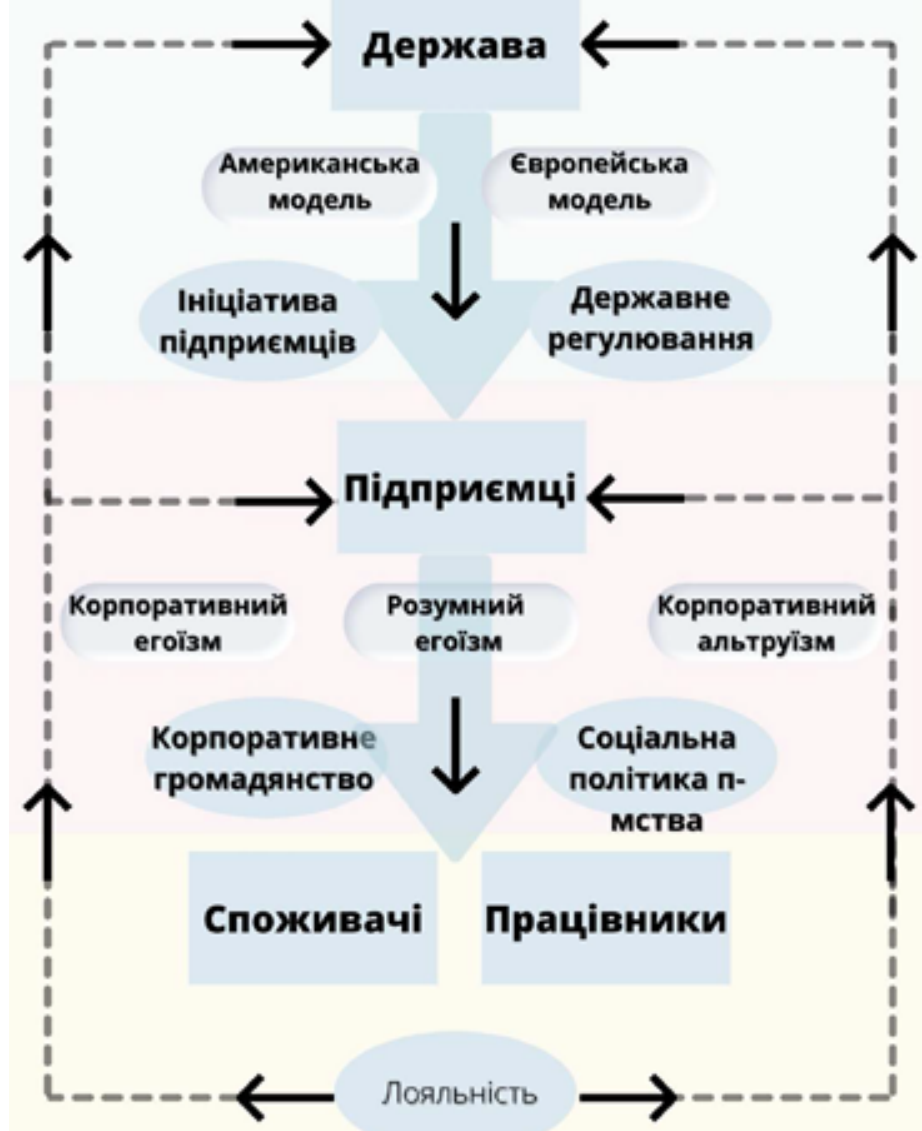

Рис. 2. Моделі підходів до розуміння корпоративної соціальної відповідальності за характеристикою гравця

Джерело: розробка авторів

ків, здебільшого КСВ для вітчизняних підприємств сприймається як одноразовий захід.

Розвиток та впровадження КСВ - складний та довготривалий процес, який в Україні лише зароджується і потребує високого рівня економічної, політичної, моральної свідомості та соціальної відповідальності гравців управління на всіх рівнях, а також відповідні матеріально-технічні умови. Проте, $є$ сподівання на те, що цей процес стане фрактором оздоровлення та розвитку національної економіки та підвищить рівень суспільного добробуту України, тож створення державного механізму розвитку та становлення корпоративної соціальної відповідальності $€$ доцільним. Серед його елементів можна виокремити:

- актуалізацію викликів сталого розвитку та промоцію корпоративної соціальної відповідальності як шляхів соціального та економічного прогресу серед макро-суспільства;

- актуалізація переваг корпоративної соціальної відповідальності для підприємницького сектору та промоція фрілософрії КСВ серед бізнесу;
- розробку та впровадження нормативноправових документів із тлумаченням КСВ, критеріями ії виміру та фрормами впровадження;

- удосконалення та активне впровадження пільгових податкових механізмів для реалізації соціальних програм;

- фрінансову підтримку підприємства 3 ефективною політикою корпоративної відповідальності;

- використання передового досвіду країн Європи та США з втілення корпоративної соціальної відповідальності, створення інсрормаційної бази з прикладами та економічним обгрунтуванням доцільності впровадження політики корпоративної соціальної відповідальності;

- залучення досвідчених іноземних фрахівців, запровадження програм навчання та обміну досвідом для вітчизняних менеджерів;

- розробка національної стратегії з розвитку корпоративної соціальної відповідальності.

Висновки. Соціально орієнтована ринкова економіка $€$ найперспективнішою моделлю організації суспільного виробництва, адже, 
вона поєднує високу ефективність ринкового механізму та орієнтацію на досягнення справедливості та рівності для усіх. Саме на таку модель орієнтується Україна, взявши на себе низку зобов'язань перед ООН та Європейським Союзом.

На жаль, поняття корпоративної соціальної відповідальності лише з'являють на слуху в українців, тоді як у Європі та США підприємства з яскравою політикою соціальної відповідальності поступово витісняють 3 ринків звичайні підприємницькі проекти. КСВ в Україні перебуває на стадії зародження, а її впровадженням займаються здебільшого великі підприємства або представництва закордонних підприємства. В умовах соціально-орієнтованої економіки лояльність, кваліфрікація та компетентність працівників стає стратегічним ресурсом та перевагою підприємства.

Впровадження корпоративної соціальної відповідальності як напрямку соціально-економічного прогресу $є$ необхідністю у сьогоднішніх реаліях. Попри те, що зараз в Україні КСВ проявляється більше як меценатство, благодійність та спонсорська допомога, і часто обумовлюється недостачею коштів підприємств, варто усвідомити, що корпоративна соціальна відповідальність, з одного боку, може стати напрямком дій для розвитку працівників, задоволення потреб та очікувань акціонерів, партнерів, постачальників підприємства, а 3 іншого боку, це напрям дій для стратегічного розширення ринку збуту та купівельної спроможності наявних та потенційних споживачів через загальне зростання добробуту суспільства. На нашу думку, для України як держави найбільш доцільним на першому етапі буде впровадження європейської моделі регулювання КСВ, яка передбачає серію заходів державного регулювання зі стимулювання КСВ. У процесі подальших дослідження цієї проблематики актуальним буде аналіз та підбір шляхів розробки та впровадження механізмів реалізації соціальної відповідальності в умовах вітчизняного законодавства, економічних умов та перспектив європейської інтеграції.

\section{СПИСОК ВИКОРИСТАНИХ ДЖЕРЕЛ:}

1. Ситник Й.С., Юрченко Г.М. Сталий розвиток та залучення соціально незахищених категорій населення до ринку праці. Міжнародний науковий журнал Інтернаука. Серія : Економічні науки, 2020, 3(35), 4. 2, 85-95.

2. Колот А.М. Корпоративна соціальна відповідальність, соціальна звітність та аудит як сучасні інститути і технології соціального розвитку. Україна: аспекти праці, 2010, 3, 3-9.

3. Калінеску Т.В., Романовська Ю.А., Кирилов О.Д. Стратегічний потенціал підприємства: фрормування та розвиток. Луганськ : СНУ ім. В. Даля, 2007.

4. Гриненко А.М. Соціальна політика підприємства: методологічний аспект. Социальнотрудовые отношения в современных экономических условиях. (Т. 2). Донецк : ИЭП НАН Украины, 2001.

5. Соціальна відповідальність бізнесу: розуміння та впровадження. URL: http://www.un.org.ua/files/ Concept_Paper.pdf

6. Вернацький В.І. Вибрані праці. Київ : Наукова думка, 2005.

7. Bowen H. Social Responsibilities of the Businessman. New York : Harper \& Row, 1953.

8. Friedman M. The Social Responsibility of Business is to increase its Profit. New York Times Magazine, 1970, 13, 122-126.

9. Caroll A. A three-dimentional conceptual model of corporate performance. Academy of Management, 1979, 4(4), 497-505.

10. Drucker P. The new meaning of corporate social responsibility. California Management Review, 1984, 26(2), 53-63.

11. Місія МОП в Україні: актуальні питання обговорено, пріоритети визначено. URL: http://www.ntser.gov.ua/ ntserprofspilku/zayavu-ta-iniciatuvu/762

12. Всесвітня бізнесова рада із сталого розвитку (WBCSD - World Business Council for Sustainable Development). URL: www.wbcsd.org

13. Post J. Redefining the Corporation and Organizational Wealth. Stanford University Press. Аналітичний звіт щодо результатів дослідження «Корпоративна соціальна відповідальність в Україні: стан та перспективи розвитку» Центру «Розвиток корпоративної соціальної відповідальності». 2002. URL: http://uniter.org.ua

14. Воробей В. Корпоративна соціальна відповідальність чи вигода? Києво-Могилянська бізнес держ. студія, 2005, 10, 11-20.

15. Зінченко О.І., Хімченко А.М. Корпоративна соціальна відповідальність в Україні: сучасні реалії та перспективи розвитку. Бізнес-інформ, 2013, 4, 281-286.

16.Колот А.М. Корпоративна соціальна відповідальність і проблеми її сприймання суспільством. Соціально-трудові відносини: теорія та практика: збірник наукових праць, 2013, 2(6), 6-14. 
17. Супрун Н.А. Корпоративна соціальна відповідальність як чинник соціального залучення (в контексті цілей стратегії «EUROPE-2020»). Український соціум, 2013, 2(45), 163-176.

18. Carroll A. Corporate social responsibility: Evolution of definitional construct. Business and Society, 1999, 38(3), 495.

19. Глобальна дослідницька маркетингова агенція Mintel. URL: https://www.mintel.com/

20. Глобальна бренд-консалтингова агенція Interbrand. URL: http://www.interbrand.com

21. Зінченко А.Г., Саприкіна М.А. Корпоративна соціальна відповідальність 2005-2010: стан та перспективи розвитку. Київ : Фарбований лист, 2010.

22. Тернова І.А. Оцінка рівня соціального та економічного розвитку України в умовах глобалізації. Соціальна економіка, 2017, 54(2), 62-71.

23.Божкова В.В., Сагер Л.Ю. Соціально відповідальний бізнес як один із напрямків поліпшення іміджу вітчизняних суб'єктів господарювання. Механізм регулювання економіки, 2010, 1, 145-153.

24. Марущак Н. Корпоративна соціальна відповідальність в Україні у контексті світового досвіду. Вісник Київського національного університету імені Тараса Шевченка. Економіка, 2012, 138, 68-71.

25. Черкасов А.В., Колесник І.А. Соціальна сорера України: проблеми та перспективи реформування. Молодий вчений, 2017, 1(41), 724-727.

26. Лебедєв І.В. Корпоративна соціальна відповідальність: модель для України. Формування ринкової економіки : зб. наук. пр., спец. вип. Економіка підприємства: теорія та практика (у 2 ч.). (Ч. II., с. 63-69). Київ : KHEY, 2010.

27.Захарчин Г.М., Склярук Т.В. Соціальні аспекти інноваційного розвитку вітчизняних підприємств. Вісник Одеського національного університету. Серія : Економіка, 2017, 11(64), 166-169.

28. Колот А.М., Грішнова О.А. та ін. Соціальна відповідальність: теорія і практика розвитку. А.М. Колот (ред.). Київ : КНЕУ, 2012.

29. Новікова О.Ф., Дейч М.Є., Панькова О.В. та ін. Діагностика стану та перспектив розвитку соціальної відповідальності в Україні (експертні оцінки). Донецьк : Ін-т економіки пром-сті НАН України, 2013.

30. Carroll A.B. A three-dimensional conceptual model of corporate performance. Academy of Management Review. 1979. Vol. 4(4). P. 500.

31. Марчук Л.П. Соціальна відповідальність як визначальна стратегія розвитку сучасного бізнесу. Науковий вісник Миколаївського державного університету імені В.О. Сухомлинського. Серія : Економічні науки, 2014, 5(2), 51-56.

32. Колот А.М. Корпоративна соціальна відповідальність: сучасна фрілософія, проблеми засвоєння. Економіка України, 2014, 3, 70-82.

\section{REFERENCES:}

1. Sytnyk Y.S., Yurchenko H.M. (2020). Stalyi rozvytok ta zaluchennia sotsialno nezakhyshchenykh katehorii naselennia do rynku pratsi [Sustainable development and involvement of socially vulnerable groups in the labor market]. Mizhnarodnyi naukovyi zhurnal Internauka. Seriia: Ekonomichni nauky, 3(35), 85-95. (in Ukrainian)

2. Kolot A.M. (2010). Korporatyvna sotsialna vidpovidalnist, sotsialna zvitnist ta audyt yak suchasni instytuty i tekhnolohii sotsialnoho rozvytku [Corporate social responsibility, social reporting and audit as modern institutions and technologies of social development]. Ukraina: aspekty pratsi, 3, 3-9. (in Ukrainian)

3. Kalinesku T.V., Romanovska Yu.A., Kyrylov O.D. (2007). Stratehichnyi potentsial pidpryiemstva: formuvannia ta rozvytok [Strategic potential of the enterprise: formation and development]. Luhansk: SNU im. V. Dalia. (in Ukrainian)

4. Hrynenko A.M. (2001). Sotsialna polityka pidpryiemstva: metodolohichnyi aspekt [Social policy of the enterprise: methodological aspect]. Sotsyalnotrudovye otnoshenyia $v$ sovremennykh ekonomycheskykh uslovyiakh.

(T. 2). Donetsk: YEP NAN Ukrayny. (in Ukrainian)

5. Sotsialna vidpovidalnist biznesu: rozuminnia ta vprovadzhennia [Corporate social responsibility: understanding and implementation]. Retrieved from: http://www.un.org.ua/files/Concept_Paper.pdf (in Ukrainian)

6. Vernatskyi V.I. (2005). Vybrani pratsi [Selected works]. Kyiv: Naukova dumka. (in Ukrainian)

7. Bowen H. (1953). Social Responsibilities of the Businessman. New York: Harper \& Row.

8. Friedman M. (1970). The Social Responsibility of Business is to increase its Profit. New York Times Magazine, 13, 122-126.

9. Caroll A. (1979). A three-dimentional conceptual model of corporate performance. Academy of Management, 4(4), 497-505.

10. Drucker P. (1984). The new meaning of corporate social responsibility. California Management Review, 26(2), 53-63. 
11. Misiia MOP v Ukraini: aktualni pytannia obhovoreno, priorytety vyznacheno [ILO mission in Ukraine: topical issues discussed, priorities identified]. Retrieved from: http://www.ntser.gov.ua/ntserprofspilku/zayavu-ta-iniciatuvu/762

12. World Business Council for Sustainable Development. Retrieved from: www.wbcsd.org

13. Post J. (2002). Redefining the Corporation and Organizational Wealth. Stanford University Press. Analitychnyi zvit shchodo rezultativ doslidzhennia «Korporatyvna sotsialna vidpovidalnist v Ukraini: stan ta perspektyvy rozvytku» Tsentru «Rozvytok korporatyvnoi sotsialnoi vidpovidalnosti» [Analytical report on the results of the study "Corporate Social Responsibility in Ukraine: Status and Prospects for Development" of the Center for the Development of Corporate Social Responsibility]. Retrieved from: http://uniter.org.ua

14. Vorobei V. (2005). Korporatyvna sotsialna vidpovidalnist chy vyhoda? [Corporate social responsibility or benefit?] Kyievo-Mohylianska biznes derzh. studiia, 10, 11-20. (in Ukrainian)

15.Zinchenko O.I., Khimchenko A.M. (2013). Korporatyvna sotsialna vidpovidalnist v Ukraini: suchasni realii ta perspektyvy rozvytku [Corporate social responsibility in Ukraine: modern realities and prospects of development]. Biznes-inform, 4, 281-286. (in Ukrainian)

16. Kolot A.M. (2013). Korporatyvna sotsialna vidpovidalnist i problemy yii spryimannia suspilstvom [Corporate social responsibility and problems of its perception by society]. Sotsialno-trudovi vidnosyny: teoriia ta praktyka: zbirnyk naukovykh prats, 2(6), 6-14. (in Ukrainian)

17. Suprun N.A. (2013). Korporatyvna sotsialna vidpovidalnist yak chynnyk sotsialnoho zaluchennia (v konteksti tsilei stratehii «EUROPE-2020») [Corporate social responsibility as a factor of social inclusion (in the context of the objectives of the strategy "EUROPE-2020")]. Ukrainskyi sotsium, 2(45), 163-176. (in Ukrainian)

18. Carroll A. (1999). Corporate social responsibility: Evolution of definitional construct. Business and Society, 38(3), 495.

19. Hlobalna doslidnytska marketynhova ahentsiia Mintel [Global research marketing agency Mintel]. Retrieved from: https://www.mintel.com/

20. Hlobalna brend-konsaltynhova ahentsiia Interbrand [Global brand consulting agency Interbrand]. Retrieved from: http://www.interbrand.com

21.Zinchenko A.H., Saprykina M.A. (2010). Korporatyvna sotsialna vidpovidalnist 2005-2010: stan ta perspektyvy rozvytku [Corporate social responsibility 2005-2010: state and prospects of development]. Kyiv: Farbovanyi lyst. (in Ukrainian)

22. Ternova I.A. (2017). Otsinka rivnia sotsialnoho ta ekonomichnoho rozvytku Ukrainy v umovakh hlobalizatsii [Assessment of the level of social and economic development of Ukraine in the context of globalization]. Sotsialna ekonomika, 54(2), 62-71. (in Ukrainian)

23. Bozhkova V.V., Saher L.lu. (2010). Sotsialno vidpovidalnyi biznes yak odyn iz napriamkiv polipshennia imidzhu vitchyznianykh subiektiv hospodariuvannia [Socially responsible business as one of the ways to improve the image of domestic businesses]. Mekhanizm rehuliuvannia ekonomiky, 1, 145-153. (in Ukrainian)

24. Marushchak N. (2012). Korporatyvna sotsialna vidpovidalnist v Ukraini u konteksti svitovoho dosvidu [Corporate social responsibility in Ukraine in the context of world experience]. Visnyk Kyivskoho natsionalnoho universytetu imeni Tarasa Shevchenka. Ekonomika, 138, 68-71. (in Ukrainian)

25. Cherkasov A.V., Kolesnyk I.A. (2017). Sotsialna sfera Ukrainy: problemy ta perspektyvy reformuvannia [Social sphere of Ukraine: problems and prospects of reform]. Molodyi vchenyi, 1(41), 724-727. (in Ukrainian)

26. Lebediev I.V. (2010). Korporatyvna sotsialna vidpovidalnist: model dlia Ukrainy [Corporate social responsibility: a model for Ukraine]. Formuvannia rynkovoi ekonomiky: zb. nauk. pr., spets. vyp. Ekonomika pidpryiemstva: teoriia ta praktyka (u 2 ch.). (Ch. II., s. 63-69). Kyiv: KNEU. (in Ukrainian)

27. Zakharchyn H.M., Skliaruk T.V. (2017). Sotsialni aspekty innovatsiinoho rozvytku vitchyznianykh pidpryiemstv [Social aspects of innovative development of domestic enterprises]. Visnyk Odeskoho natsionalnoho universytetu. Seriia: Ekonomika, 11(64), 166-169. (in Ukrainian)

28. Kolot A.M., Grishnova O.A., etc. (2012). Sotsial'na Vidpovidal'nist': Teoriya i Praktyka Rozvytku [Social responsibility: theory and practice of development]. Kyiv: KNEU. (in Ukrainian)

29. Novikova O.F., Deich M.E., Pan'kova O.V. etc. (2013). Diagnostyka Stanu ta Perspektyv Rozvytku Sotsial'noi Vidpovidal'nosti v Ukraini (Ekspertni Otsinky) [Diagnosis of the State and Perspectives of the Development of Social Responsibility in Ukraine (Expert Estimates)]. Donets'k: Inst. of Industr. Econ. of the NASU. (in Ukrainian)

30. Carroll A.B. (1979). A three-dimensional conceptual model of corporate performance. Academy of Management Review, vol. 4(4), p. 500.

31. Marchuk L.P. (2014). Sotsialna vidpovidalnist yak vyznachalna stratehiia rozvytku suchasnoho biznesu [Social responsibility as a defining strategy for the development of modern business.]. Naukovyi visnyk Mykolaivskoho derzhavnoho universytetu imeni V.O. Sukhomlynskoho. Seriia: Ekonomichni nauky, 5(2), 51-56. (in Ukrainian)

32. Kolot A.M. (2014). Korporatyvna sotsialna vidpovidalnist: suchasna filosofiia, problemy zasvoiennia [Corporate social responsibility: modern philosophy, problems of assimilation]. Ekonomika Ukrainy, 3, 70-82. (in Ukrainian) 